Sains Malaysiana 50(1)(2021): 53-61

http://dx.doi.org/10.17576/jsm-2021-5001-06

\title{
Genetic Characterization of the Central Javanese Duck using Microsatellite Markers
}

(Pencirian Genetik Itik Asli Jawa Tengah menggunakan Penanda Mikrosatelit)

R SUSANTI*, ARI YUNiASTUTI \& AgUSTIN DiAn KARTIKASARI

ABSTRACT

Duck conservation strategy based on genetic characteristics has been undertaken to preserve indigenous breeds and produce high quality offspring. In addition, the genetic characteristic analysis provides further information for studying avian influenza viruses. The aim of this research was to study the genetic characterisation of indigenous Central Javanese duck in Indonesia using microsatellite markers. Microsatellite or simple sequence repeats (SSR) or short tandem repeats (STR) of various breeds of Central Javanese duck were analysed on 35 local ducks which consisted of seven variants of Javanese ducks in Central Java. Ten pairs of duck microsatellite primers were used to amplify the DNA from feathers. Nine out of 10 microsatellite loci (90\%) demonstrated polymorphic patterns containing 50 alleles. The number of alelles varied from two to 10 alleles at various polymorphic microsatellite loci with an average of 5.56 alelles per locus. From the study, CAUD013 locus was determined as the highest heterozygosity with 0.882 score while CAUD030 locus was the lowest one with 0.034 score. Similarly, CAUD030 locus had the lowest PIC score (0.30) whereas the CAUD013 locus had the highest PIC value (0.869). Hence, it was showed that microsatellite markers were highly polymorphic in several loci for the Central Javanese duck and may be useful for genetic description of other native duck in terms of species conservation.

Keywords: Central Javanese Duck; genetic characterization; microsatellite

ABSTRAK

Strategi pemuliharaan itik berdasarkan pencirian genetik telah dijalankan untuk mengekalkan baka asli dan menghasilkan keturunan yang berkualiti tinggi. Di samping itu, analisis ciri genetik itik memberikan maklumat lanjut untuk mengkaji virus influenza avian. Tujuan penyelidikan ini adalah untuk mengkaji ciri genetik itik asli Jawa Tengah di Indonesia menggunakan penanda mikrosatelit. Mikrosatelit atau jujukan mudah berulang (SSR) atau jujukan tandem pendek (STR) daripada pelbagai baka itik Jawa Tengah telah dianalisis ke atas 35 ekor itik tempatan yang terdiri daripada tujuh varian itik Jawa di Jawa Tengah. Sebanyak 10 pasang primer mikrosatelit itik telah digunakan untuk mengamplifikasi DNA daripada bulu. Sebanyak 9 daripada 10 lokus mikrosatelit (90\%) menunjukkan corak polimorfik yang mengandungi 50 alel. Bilangan alel didapati antara 2 hingga 10 alel di pelbagai lokus polimorfik mikrosatelit dengan purata 5.56 alel bagi setiap lokus. Daripada kajian ini, lokus CAUD013 telah ditentukan sebagai heterozigositi tertinggi dengan skor 0.882 manakala lokus CAUD030 adalah heterozigositi terendah dengan skor 0.034. Begitu juga, lokus CAUD030 mempunyai skor PIC terendah (0.30) sementara lokus CAUD013 mempunyai skor PIC tertinggi (0.869). Oleh itu, hasil telah menunjukkan bahawa penanda mikrosatelit mempunyai tahap polimorfik tertinggi pada beberapa lokus untuk itik Jawa Tengah dan kemungkinan berguna untuk deskripsi genetik itik asli yang lain untuk keperluan pemuliharaan.

Kata kunci: Itik Jawa Tengah; mikrosatelit; pencirian genetik

\section{INTRODUCTION}

Duck is the familiar name for species in the waterfowl family, Anatidae. Ducks are shared among several subfamilies; however, they do not represent a monophyletic group (Johnsgard 1961). Some species are endemic, in the critically endangered status and threatened by human activities (Green 1996). In some countries, high wild duck consumption decreases most of the exotic duck species populations. The decreasing population is also continued along the bird's flyway during migration season, such as in South Korea (Kraus et al. 2011). Duck characterisation and conservation efforts are essential in stabilising and providing food stock. In addition, the waterfowl, especially domesticated duck, is an essential natural reservoir for 
an infectious disease control caused by duck resistance against pathogenic virus or bacteria (Gaur et al. 2016). The Food and Agriculture Organisation of the United Nations recommended a conservation programme for maintaining animal genetic resources (Adzitey \& Adzitey 2011). These included many other actions such as identification and characterisation of local breeds. Limited information about local duck genetic characterisation for breeding program will disrupt the introduction of exotic breeds germplasm.

Most current genetic data resources in terms of studying duck are available only for heritability and genetic relationship of some traits (Bochno et al. 2000) and epidemic disease cases (Susanti et al. 2008). Moreover, molecular data availability only comes from mitochondrial DNA sequence to study evolution and phylogenetic (Jin et al. 2014, 2012; Susanti et al. 2017). Since the study about genetic polymorphism markers in duck is limited (Alyethodi \& Kumar 2010; Kraus et al. 2011; Seo et al. 2016), therefore, we characterised 10 microsatellite markers for Central Javanese duck. The markers have been used for genetic mapping in duck population and breeding, the correlation among animals, medical applications, genetic population, and ecological improvement (Bochno et al. 2000).

Microsatellite or simple sequence repeats are short repetitive elements of 1 to 6 bases which originated in all eukaryotic and even prokaryotic genomes (Schlötterer 2000), present in both noncoding and coding region (Ellegren 2004), and smaller than 100 bp (Stolle et al. 2013). Microsatellite sequences are polymorphic, copious, reproducible, and inherited co-dominantly (Saavedra et al. 2013). The microsatellite is chosen as a marker for diversity and relationship analysis among diverse species of poultry and livestock including camel, buffalo, and horse, especially for native species (Vijh et al. 2008, 2007), and for characterising genetic diversity in farm animals (Simianer 2006). It can also be used for genetic and phylogenetic diversity analysis of indigenous and exotic duck breed (Veeramani et al. 2014), and gender identification (Huang et al. 2013).

Microsatellites are effective as molecular markers for genetic population analysis, genome mapping, genetic fingerprinting, linkage analysis, and taxonomic study and diversity (Olango et al. 2015). Microsatellite markers can be developed as a conservation strategy to preserve pure breeds and the high quality inherited in their descendents. In addition, duck breed taxonomy and characteristic analysis provide further information for studying avian influenza viruses (Groepper et al. 2014; Ramey et al. 2014). Hence, this study was conducted to characterise the indigenous Central Javanese duck breeds in Indonesia using microsatellite markers.

\section{MATERIALS AND METHODS}

\section{SAMPLE PREPARATION}

Thirty-five local ducks were used for this research, which consisted of seven variants of Javanese Anas platirhyncus L. namely Peking duck (IK1-5), and ducks from districts around Central Java such as Magelang (IM1-5), Pengging (IG1-5), Tegal Branjangan (ITB1-5), Tegal Jarakan (ITJ1-5), Tegal Blorong (ITL1-5) and Tegal Lemahan (ITP1-5). The ducks were collected from Balai Pembibitan dan Budi Daya Ternak Non Ruminansia (BPBTNR) Dinas Kesehatan Hewan (Dinkeswan) Satuan Kerja Itik Banyubiru, Semarang District (Non-Ruminant Cultivation and Livestock Breeding Center, Animal Health Service, Banyubiru Duck Work Unit, Semarang District). The left-wing feather follicle was taken from the ducks. It was only about 4 to $5 \mathrm{~cm}$ from the feather base part of calamus and rachis, which was filled with marrow and had many veins. DNA isolation was conducted using gSYNC ${ }^{\text {TM }}$ DNA Extraction Kit (GeneAID Biotech Ltd, New Taipei City, Taiwan).

\section{MICROSATELLITE MARKERS AND PCR}

Amplification procedure was completed using KAPA 2G HotStart Ready Mix Kit (Kapa Biosystems, Massachusetts) which consisted of $12.5 \mu \mathrm{L}$ of ready mix, $1.5 \mu \mathrm{L}$ of forward primer, $1.5 \mu \mathrm{L}$ of reverse primer, $7.5 \mu \mathrm{L}$ of $\mathrm{ddH}_{2} \mathrm{O}$ and $2.0 \mu \mathrm{L}$ of DNA samples. Ten pairs of duck microsatellite primers were used to amplify the genomic DNA. The sequence of the microsatellite primers was reported by Huang et al. (2005) (Table 1). The PCR program was operated following several steps which included pre-denaturation at $94{ }^{\circ} \mathrm{C}$ for $5 \mathrm{~min}$, followed with $94{ }^{\circ} \mathrm{C}$ for $1 \mathrm{~min}$ for denaturation, 50.9 to $60.4{ }^{\circ} \mathrm{C}$ for annealing (Table 1) for $45 \mathrm{~s}$, an extension step of $72^{\circ} \mathrm{C}$ for $1 \mathrm{~min}$, and a final extension at $72{ }^{\circ} \mathrm{C}$ for $5 \mathrm{~min}$. The amplification cycle was repeated 35 times.

The amplification products were run on a polyacrylamide gel electrophoresis (PAGE) $0.4 \mathrm{~mm}$ thick with $6 \%$ of polyacrylamide $(29: 1)$ at $900 \mathrm{~V}$ for $2 \mathrm{~h}$. The gel was fixed in the glass plate and stained with silver. The molecular sizes of alleles were calculated using Alpha Imager software of Alpha Imager ${ }^{\circledR} \mathrm{EP}$ (Cell Biosciences Inc., Santa Clara, CA).

Heterozygosity $(\mathrm{He})$ for each microsatellite marker was calculated using a formula according to Nei (1987):

$$
H_{i}=\frac{2 N}{2 N-1}\left[1-\sum_{j=1}^{l} P j^{2}\right]
$$

where $P_{j}$ is the frequency of the $j$ th allele at the $i$ th locus with $k$ number of alleles in population and $N$ is the number of individuals. 
TABLE 1. Microsatellite primers in this study with different optimised temperature (modified) and annealing temperature from previous research

\begin{tabular}{|c|c|c|c|c|c|}
\hline \multirow[b]{2}{*}{ Loci } & \multirow{2}{*}{\multicolumn{2}{|c|}{ Base sequence }} & \multirow{2}{*}{ Repeat types } & \multicolumn{2}{|c|}{ Annealing temperature $\left({ }^{\circ} \mathrm{C}\right)$} \\
\hline & & & & Modifiication in & (Huang et \\
\hline \multirow{2}{*}{ CAUD001 } & $\mathrm{F}$ & 5'- ACAGCTTCAGCAGACTTAGA-3' & (AAAAC)3A6G(CA)9A33 & 55.5 & 55.5 \\
\hline & $\mathrm{R}$ & 5'- GCAGAAAGTGTATTAAGGAAG-3' & & & \\
\hline \multirow[t]{2}{*}{ CAUD002 } & $\mathrm{F}$ & 5'- CTTCGGTGCCTGTCTTAGC-3' & (CAG)6 & 60.4 & 60.8 \\
\hline & $\mathrm{R}$ & 5'- AGCTGCCTGGAGAAGGTCT-3' & & & \\
\hline \multirow[t]{2}{*}{ CAUD005 } & $\mathrm{F}$ & 5'- CTGGGTTTGGTGGAGCATAA-3' & (CT) 18 & 60.4 & 60.8 \\
\hline & $\mathrm{R}$ & 5'- TACTGGCTGCTTCATTGCTG-3' & & & \\
\hline \multirow[t]{2}{*}{ CAUD011 } & $\mathrm{F}$ & 5'- TGCTATCCACCCAATAAGTG-3' & (CA) 13 & 50.9 & 50.3 \\
\hline & $\mathrm{R}$ & 5'- CAAAGTTAGCTGGTATCTGC-3' & & & \\
\hline \multirow[t]{2}{*}{ CAUD013 } & $\mathrm{F}$ & 5'- ACAATAGATTCCAGATGCTGAA-3' & $(\mathrm{AC}) 25$ & 58.1 & 58.1 \\
\hline & $\mathrm{R}$ & 5'- ATGTCTGAGTCCTCGGAGC-3' & & & \\
\hline \multirow[t]{2}{*}{ CAUD016 } & $\mathrm{F}$ & 5'- TTTAGGTAAAACTGTGAATCAA-3' & T8(TTTC)8T13 & 52.1 & 51.4 \\
\hline & $\mathrm{R}$ & 5'- ATCAAAGCAGGGAGCTAAG-3' & & & \\
\hline \multirow[t]{2}{*}{ CAUD022 } & $\mathrm{F}$ & 5'- CATGCTGAGTGTCCTATCCT-3' & $(\mathrm{GCA}) 8$ & 50.9 & 55.5 \\
\hline & $\mathrm{R}$ & 5'- CCAGGTCAGGCGTGTGCT-3' & & & \\
\hline \multirow[t]{2}{*}{ CAUD030 } & $\mathrm{F}$ & 5'- ATTATTCCTGATGGCGTGGT-3' & (CA)9 ...(AT)6T10 & 50.9 & 50.3 \\
\hline & $\mathrm{R}$ & 5'- TCATGCTGAATTTGGCTGTT-3' & & & \\
\hline \multirow[t]{2}{*}{ CAUD031 } & $\mathrm{F}$ & 5'- AGCATCTGGACTTTTTCTGGA-3' & (TTTC)9(TC)25 & 52.1 & 51.4 \\
\hline & $\mathrm{R}$ & 5'- CACCCCAGGCTCTGAGATAA-3' & & & \\
\hline \multirow[t]{2}{*}{ CAUD032 } & $\mathrm{F}$ & 5'- GAAACCAACTGAAAACGGGC-3' & $(\mathrm{CA}) \mathrm{n}$ & 58.1 & 58.1 \\
\hline & $\mathrm{R}$ & 5'- CCTCCTGCGTCCCAATAAG-3' & & & \\
\hline
\end{tabular}

After that, the polymorphic information content (PIC) score was calculated using a formula according to Botstein et al. (1980):

$$
\mathrm{PIC}=1-\sum_{i=1} P i^{2}-2 \sum_{j=i} \sum_{i=j+1} P i^{2} P j^{2}
$$

where $\mathrm{P}_{i}$ and $\mathrm{P}_{j}$ are the frequencies of $i$ th and $j$ th allele, respectively, at a locus with $\mathrm{n}$ alleles in a population.

Kinship relationships were analysed through the unweighted pair group method using the arithmetic mean with numerical taxonomy and multivariate analysis system (NTSYSpc) version 2.01 (Rohlf 1998), the phylogenetic three was built up by following software's protocol. Genetic similarity coefficients between individuals were processed using SIMQUAL procedures and calculated based on the Dice coefficient from Sneath and Sokal (1973).

\section{RESULTS}

In this research, the PCR cycle profile and annealing temperature during DNA amplification were modified from Huang et al. (2005) (Table 1). Temperature optimisation was attempted several times from 50 to 62 ${ }^{\circ} \mathrm{C}$ until the appropriate temperatures were obtained. It was conducted to reduce debris and residues from the PCR process, improve product quality and score the 
amplicons on the gel easily. An electrophoresis process of polyacrylamide gel has a high resolution to distinguish base pair length of alleles even for 2 bp (Figures $1 \& 2$ ). The bands observed on silver-stained polyacrylamide gel did not show unwanted bands that interfered the scoring process. The allele sizes appeared in lengths varying from 85 to $600 \mathrm{bp}$, and 9 out of 10 loci (90\%) were polymorphic.
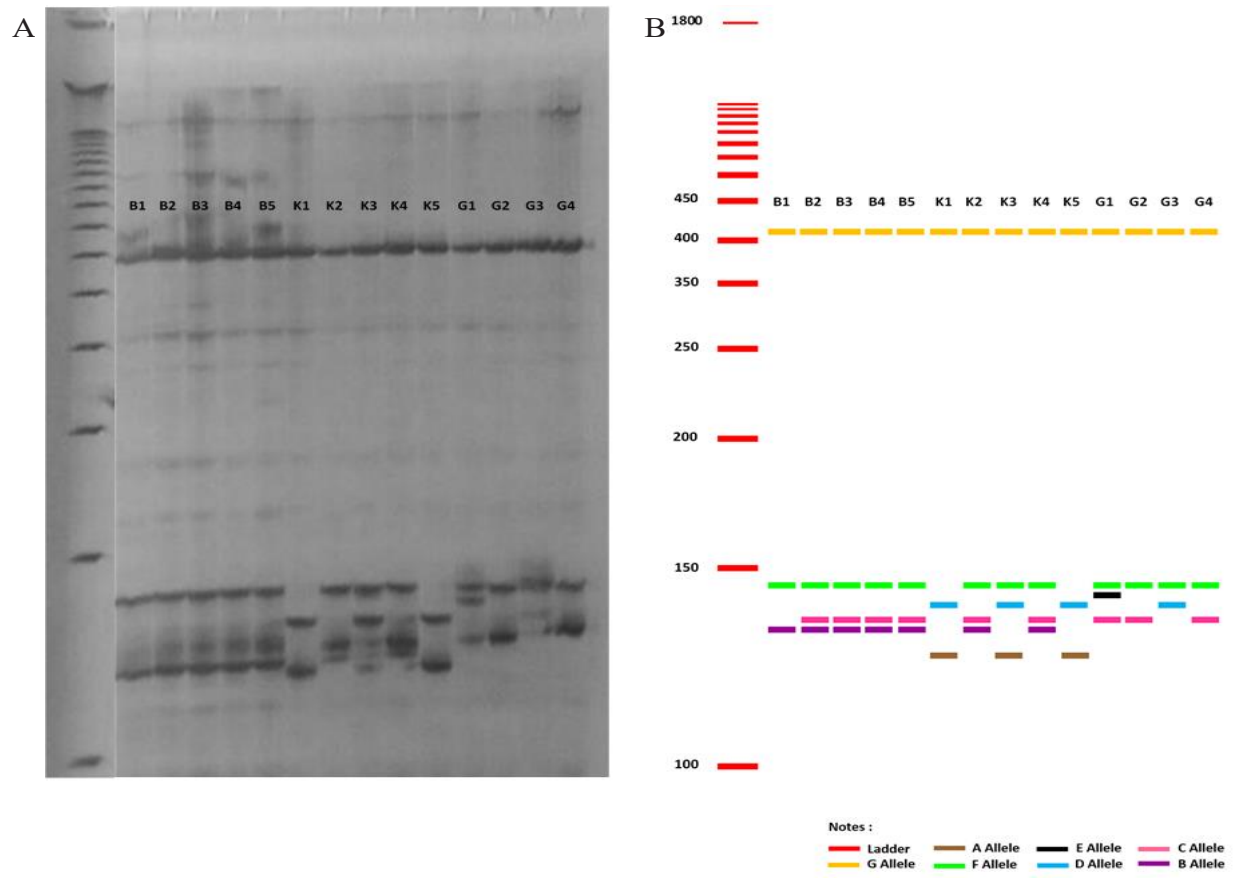

FIGURE 1. Allele visualisation by DNA sequences where B1-B5 represented Tegal Branjangan duck (ITB), K1-K5 for Peking duck (IK) and G1-G5 for Pengging Duck (IG) on A) polyacrylamide gel electrophoresis, and B) zymogram. The coloured band indicated DNA sequence positions on the polyacrylamide gel where different colours indicated different alleles and sequence lengths
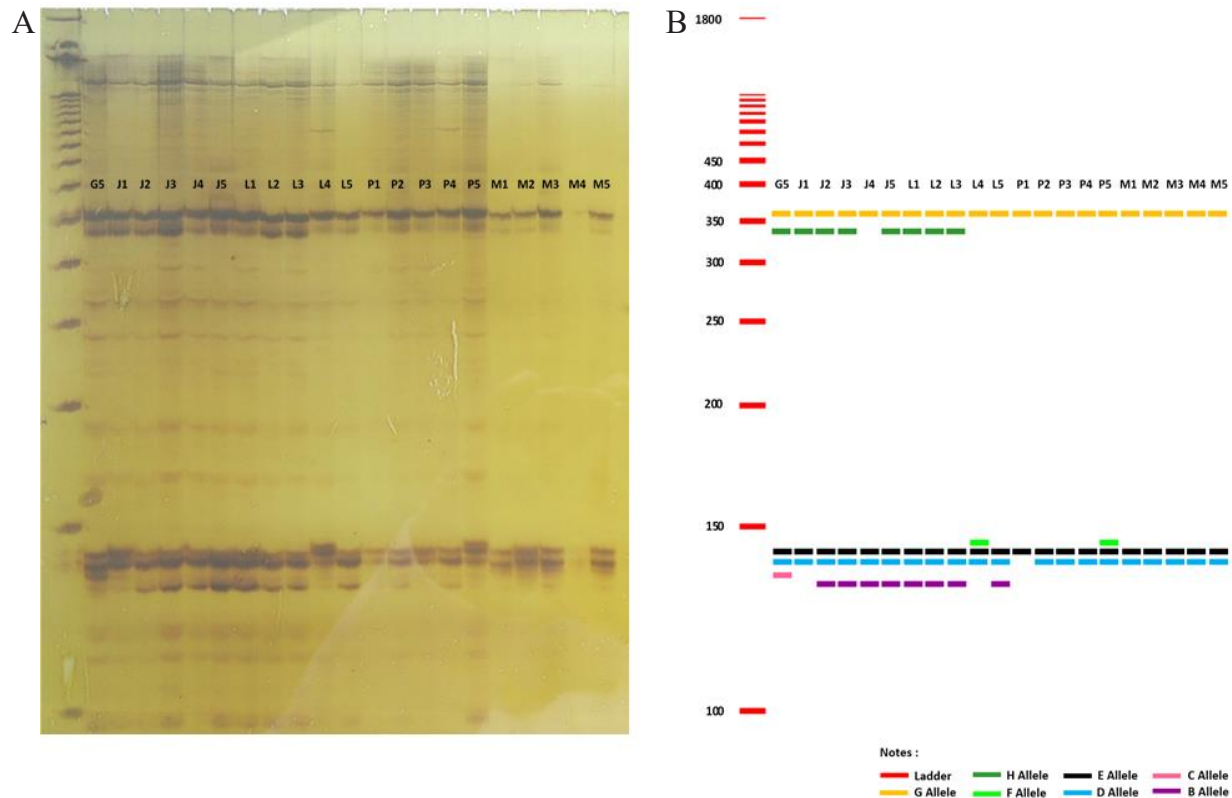

FIGURE 2. Allele visualisation by DNA sequences where G5 represented Pengging Duck (IG), J1-J5 for Tegal Jarakan (ITJ), L1-L5 for Tegal Blorong Duck (ITL), P1-P5 for Tegal Lemahan (ITP) and M1-M5 for Magelang (IM) on A) polyacrylamide gel electrophoresis, and B) zymogram. The coloured bands indicated DNA sequence positions on the polyacrylamide gel where different colours indicated different alleles and sequence lengths 
Overall, 50 alleles were identified from nine polymorphic loci (Table 2). The alleles varied from 2 to 10 polymorphic loci, where the most abundant alleles were observed in CAUD013 locus and the lowest was in CAUD030 locus. Furthermore, the average number of alleles per locus was 5.56 where the average PIC score for the Central Javanese duck microsatellite was
0.685. The PIC scores for nine polymorphic loci studied were quite high and ranged from 0.30 (CAUD030) to 0.869 (CAUD013). There were eight from nine loci $(88.8 \%)$ with PIC score greater than 0.5 . The expected heterozygosity scores for various loci ranged between 0.304 (CAUD030) to 0.882 (CAUD013) with a mean score of 0.695 (Table 2).

TABLE 2. The characteristics of the microsatellite markers in the Central Javanese duck

\begin{tabular}{|c|c|c|c|c|c|c|c|c|}
\hline No & Locus & Fragment (bp) & Allele No & $\mathrm{He}$ & PIC & Allele & Size & Frequency \\
\hline \multirow[t]{5}{*}{1} & CAUD001 & $315-331$ & 5 & 0.596 & 0.588 & A & 315 & 0.241 \\
\hline & & & & & & B & 317 & $0.586^{* *}$ \\
\hline & & & & & & $\mathrm{C}$ & 321 & 0.069 \\
\hline & & & & & & D & 323 & 0.035 \\
\hline & & & & & & E & 331 & 0.069 \\
\hline 2 & CAUD002 & $188-188$ & 1 & 0 & 0 & A & 188 & 1 \\
\hline \multirow[t]{6}{*}{3} & CAUD005 & $250-300$ & 6 & 0.696 & 0.686 & A & 250 & 0.0213 \\
\hline & & & & & & B & 259 & 0.3617 \\
\hline & & & & & & $\mathrm{C}$ & 267 & 0.4043 \\
\hline & & & & & & D & 282 & 0.1064 \\
\hline & & & & & & E & 284 & 0.0850 \\
\hline & & & & & & $\mathrm{F}^{*}$ & 300 & 0.0213 \\
\hline \multirow[t]{4}{*}{4} & CAUD011 & $121-140$ & 4 & 0.760 & 0.749 & A & 121 & 0.234 \\
\hline & & & & & & B & 127 & 0.259 \\
\hline & & & & & & $\mathrm{C}$ & 131 & 0.273 \\
\hline & & & & & & D & 140 & 0.234 \\
\hline \multirow[t]{10}{*}{5} & CAUD013 & $85-600$ & 10 & 0.882 & 0.869 & A & 85 & 0.036 \\
\hline & & & & & & B & 91 & 0.036 \\
\hline & & & & & & $\mathrm{C}$ & 95 & 0.155 \\
\hline & & & & & & D & 105 & 0.155 \\
\hline & & & & & & E & 107 & 0.173 \\
\hline & & & & & & F & 111 & 0.173 \\
\hline & & & & & & G & 113 & 0.091 \\
\hline & & & & & & $\mathrm{H}^{*}$ & 116 & 0.091 \\
\hline & & & & & & $I^{*}$ & 575 & 0.045 \\
\hline & & & & & & $\mathrm{J}^{*}$ & 600 & 0.045 \\
\hline \multirow[t]{5}{*}{6} & CAUD016 & $189-217$ & 5 & 0.745 & 0.734 & A & 189 & 0.100 \\
\hline & & & & & & B & 193 & 0.125 \\
\hline & & & & & & $\mathrm{C}$ & 209 & 0.300 \\
\hline & & & & & & D & 213 & 0.375 \\
\hline & & & & & & E & 217 & 0.100 \\
\hline
\end{tabular}




\begin{tabular}{|c|c|c|c|c|c|c|c|c|}
\hline \multirow[t]{8}{*}{7} & CAUD022 & $120-380$ & 8 & 0.846 & 0.834 & $A^{*}$ & 120 & 0.024 \\
\hline & & & & & & $\mathrm{B}$ & 128 & 0.118 \\
\hline & & & & & & $\mathrm{C}$ & 133 & 0.079 \\
\hline & & & & & & $\mathrm{D}$ & 137 & 0.173 \\
\hline & & & & & & $\mathrm{E}$ & 140 & 0.165 \\
\hline & & & & & & $\mathrm{F}^{*}$ & 145 & 0.110 \\
\hline & & & & & & $\mathrm{G}^{*}$ & 340 & 0.268 \\
\hline & & & & & & $\mathrm{H}^{*}$ & 380 & 0.063 \\
\hline \multirow[t]{2}{*}{8} & CAUD030 & $257-261$ & 2 & 0.304 & 0.300 & A & 257 & $0.816^{* *}$ \\
\hline & & & & & & B & 261 & 0.184 \\
\hline \multirow[t]{6}{*}{9} & CAUD031 & $112-130$ & 6 & 0.790 & 0.779 & A & 112 & 0.183 \\
\hline & & & & & & B & 114 & 0.209 \\
\hline & & & & & & $\mathrm{C}$ & 118 & 0.052 \\
\hline & & & & & & $\mathrm{D}$ & 126 & 0.269 \\
\hline & & & & & & $\mathrm{E}^{*}$ & 128 & 0.261 \\
\hline & & & & & & $\mathrm{F}^{*}$ & 130 & 0.026 \\
\hline \multirow[t]{5}{*}{10} & CAUD032 & $115-125$ & 4 & 0.636 & 0.627 & A & 115 & $0.542 * *$ \\
\hline & & & & & & B & 117 & 0.125 \\
\hline & & & & & & $\mathrm{C}$ & 121 & 0.229 \\
\hline & & & & & & $\mathrm{D}^{*}$ & 125 & 0.104 \\
\hline & rage (Exclu & UD002) & 5.56 & 0.695 & 0.685 & & & \\
\hline
\end{tabular}

*Specific alleles on Central Javanese duck.

**Frequency alleles more than 0.500

The allele frequency for various loci ranged between 0.0213 and 0.816 . There were three alleles from 50 alleles scored higher than 0.5 (Table 2). The frequencies of most alleles were high. At least 33 alleles out of 50 (66\%) polymorphic alleles had frequency more than $10 \%$. Alleles with frequency levels about $10 \%$ may be more suitable to tag to a specific population (Rajkumar et al. 2008). This suggested that the alleles can be used as characterisation markers for the Central Javanese duck population as distinct populations with other indigenous Indonesian ducks.

Further analysis showed the presence of specific alleles in Central Javanese duck breeds (Table 3). The emergence of these specific alleles raised the notion that these strains have typical phenotypic properties since molecular markers are often located near genes. Fifty-one alleles were detected from ten microsatellite loci in the seven breeds. The average number of allele per breed of duck varied from 2.9 to 3.3 (data not shown).

TABLE 3. Alleles unique to certain breeds of central Javanese duck

\begin{tabular}{ccccc}
\hline No & Breed & Specific-Allele & Size $(\mathrm{bp})$ & Locus \\
\hline 1. & ITB & C1 & 321 & CAUD001 \\
& & D1 & 323 & \\
& & E1 & 331 & \\
2. & A3 & 250 & CAUD005 \\
3. & IK & A7 & 120 & CAUD022 \\
& IG & I5 & 575 & CAUD013 \\
4. & J5 & 600 & \\
\hline
\end{tabular}


Based on the phylogeny analysis, a dendrogram consisted of two clusters (Figure 3). The first cluster consisted of Tegal Branjangan duck (ITB) and Peking duck (IK), where all other duck samples were included in the second cluster and formed two sub-clusters. The first sub-cluster 1 consisted of Pengging duck (IG), and the second sub-cluster included Tegal Jarakan duck (ITJ),
Tegal Blorong duck (ITL), Tegal Lemahan duck (ITP) and Magelang duck (IM) (Figure 1). Another research also showed that the genetic relationship between Tegal and Magelang duck is very close based on microsatellite markers (ADL-115, ADL-209, ADL-231, APH-23, APH-24 and APH-09) (Matitaputty et al. 2015).

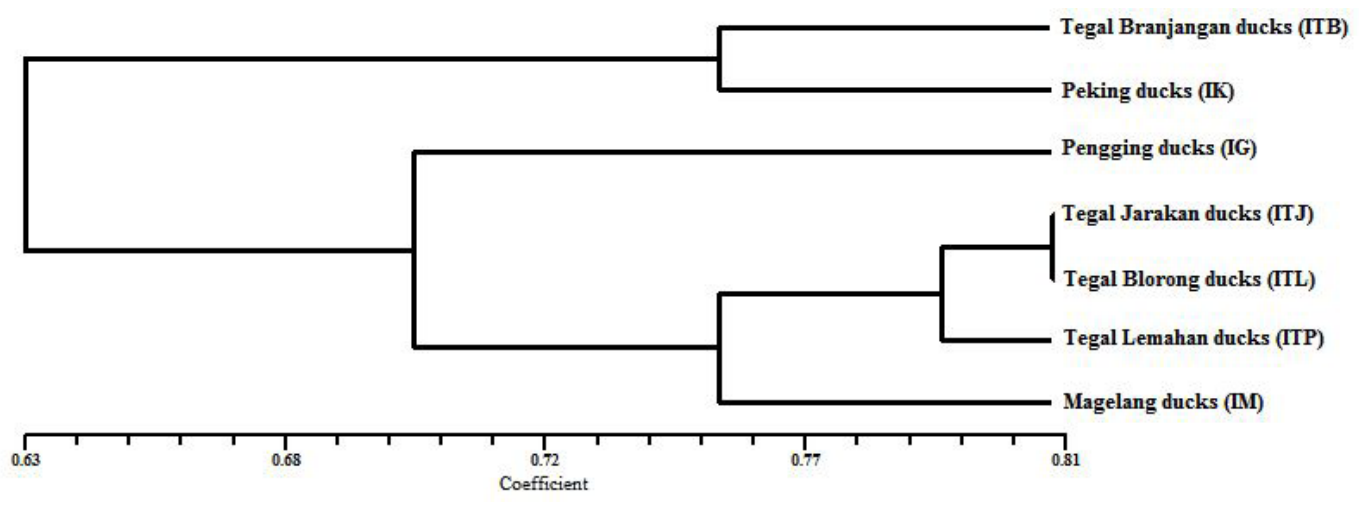

FIGURE 3. Dendrogram of the genetic relationships among seven breeds of Central Javanese duck based on microsatellite markers

\section{DISCUSSION}

The native species breeds need to be preserved for biodiversity conservation and development of ecologically important traits, which would also be valuable for human food security and duck breed survival. All microsatellite primers used in this study were useful in characterising the Central Javanese ducks as shown by clear bands of the PCR products. The bands on the polyacrylamide gel consisted of one allele from each microsatellite locus.

The examined microsatellite loci from moderate to high polymorphic rates suggested that they may be useful as genetic characterisation marker of other duck breeds as well. The PIC score is a good index of genetic diversity evaluation where PIC score higher than 0.500 indicates high gene diversity. On the other hand, PIC score lower than 0.25 indicates low diversity, and then the middle range between 0.25 and 0.5 indicates intermediate diversity (Botstein et al. 1980). Based on this information, all polymorphic microsatellite loci, excluding CAUD030 locus, have enough discrimination power to distinguish individuals and breeds in population.

The application of domestic duck markers for CAUD-G locus set is effective in identifying the alleles, and $75 \%$ of them are polymorphic to Zatorska geese (Andres \& Kapkowska 2011). In previous research on Pecking genome, the microsatellite of CAUD002 locus was stated as monomorphic allele (Huang et al. 2005) as well as in Central Javanese duck, but it was polymorphic (two alleles) in Moti Indian duck (Alyethodi \& Kumar 2010).

The highest polymorphism in Javanese Duck was detected in CAUD013 locus composed of 10 alleles, and was also the highest polymorphic locus found in the Moti Indian duck composed of five alleles (Alyethodi \& Kumar 2010), seven alleles in the Peking duck (Huang et al. 2005), and 11 alleles in the Indian duck (Gaur et al. 2016). The high polymorphism in Central Javanese duck alleles indicated high genetic difference among duck population.

On the other hand, Huang et al. (2005) reported that there were five alleles with 0.30 of PIC score in the CAUD005 locus of Peking duck population, and nine alleles with 0.728 of PIC score in Asian duck population (Seo et al. 2016). It suggested that the variation in the Asian duck was higher than Central Javanese duck, followed by the Peking duck. Alyethodi and Kumar (2010) reported a variation of 21 microsatellite markers from Indian native Moti duck breed, which had a PIC score lower than Asian duck. The PIC score for CAUD005 locus in the Moti Indian duck was 0.55 , which was 0.178 lower than the Asian duck (Seo et al. 2016), and 0.136 lower than the Central Javanese duck, but 0.25 higher than the Peking duck (Huang et al. 2005). 
Huang et al. (2005) also reported four alleles with 0.40 of PIC score from CAUD031 locus of the Peking duck population, and 15 alleles with 0.62 of PIC score in the Indian duck population (Gaur et al. 2016), which suggested that the variation in the Indian duck population was higher than the Peking duck. Meanwhile, in the Asian duck population, PIC score of CAUD031 locus was 0.533 , which was composed of 10 alleles (Seo et al. 2016), but in this study, the PIC score of CAUD031 locus was only 0.779 , which was composed of six alleles, and it indicated that the Central Javanese ducks were relatively varied in species. However, these results still need to be validated because of the different sample sizes may cause high variations. In the previous study of the Asian duck, the researcher was used 243 samples from eight different populations (Seo et al. 2016), while, in this research was only 35 sample from six populations.

Gaur et al. (2016) reported that there are 19 alleles and 0.68 of PIC score in CAUD001 of Indian duck population, but it is only four alleles and 0.6 of PIC score in Moti Indian duck population. Moreover, in this research, it is only five alleles with PIC score of 0.588 in Central Javanese duck. From those data, the variation in the Indian duck is higher than Central Javanese duck and Moti Indian duck. After that, the same marker for CAUD001 locus shows that Peking duck has 0.51 of PIC score (Huang et al. 2005), which is 0.17 lower than Indian duck (Gaur et al. 2016), 0.09 lower than Moti Indian duck (Alyethodi \& Kumar 2010), and 0.078 lower than Central Javanese duck. Wu et al. (2009) reported that there are five alleles and 0.422 of PIC score in the CAUD001 of Beijing duck, and six alleles and 0.698 of PIC score in Cherry Valley duck.

The PIC score represents an expected score for heterozygosity that can be assumed as the number of alleles in very short frequency. The eight from nine polymorphic loci in Central Javanese duck have PIC score higher than Peking duck (Huang et al. 2005). The average PIC score observed from all polymorphic microsatellite's loci in the present investigation was 0.685 , whereas, Huang et al. (2005), who analyses the same set of microsatellite's loci, estimated overall PIC score as 0.41 \pm 0.01 in Pecking duck. The average PIC score of the Southeast Asian duck is 0.584 (Seo et al. 2016). Genetic differences in the analyzed populations may cause the different PIC score of various microsatellite loci.

An observation about alleles on all polymorphic loci in this research was successfully found 11 specific alleles that only exist in Central Javanese duck (Table 2), but none of them found in Peking duck (Huang et al. 2005). The absence of specific alleles in other loci is possible because the loci have few polymorphic sites or have a limited number of analyzed breeds. Additional loci and number of breed samples need to be analyzed to ensure the validity of data and obtain higher polymorphisms and certain specific alleles (Čerenak et al. 2004). Different genetic structures may cause differences in polymorphic patterns in various microsatellites' loci in different breeds. This observation demonstrates it existed variations among breeds. It also exhibits different alleles in different population create genetic diversity in the universe for livestock sustainability that needs to be conserved (Alyethodi \& Kumar 2010).

\section{CONCLUSION}

The results of this research showed that microsatellite markers were polymorphic in the Central Javanese duck. As many as 33 alleles from 50 alleles $(66 \%)$ are polymorphic alleles that had frequency more than $10 \%$. It can be used as a characterization marker for Central Javanese to distinguish with other indigenous Indonesian ducks. High level of polymorphism microsatellite locus proposed that these markers may be useful for genetic description of native duck and to get the pure breed as a conservation effort of various specific-species that has important contribution to the environment.

\section{ACKNOWLEDGEMENTS}

The authors would like to thank the Research and Community Servis Center of Universitas Negeri Semarang for the research funding support through PUPT Research Grant Fiscal Year 2017 No. 1.7.4/UN37/PPK.3.1/ 2017, 7 April 2017.

\section{REFERENCES}

Adzitey, F. \& Adzitey, S. 2011. Duck production: Has the potential to reduce poverty among rural households in Asian communities - A review. Journal of World's Poultry Research 1: 7-10.

Alyethodi, R.R. \& Kumar, S. 2010. Genetic characterization of moti indian native duck using microsatellite markers. Journal of Applied Animal Research 38(2): 223-227.

Andres, K. \& Kapkowska, E. 2011. Applicability of anatid and galliform microsatellite markers to the genetic diversity studies of domestic geese (Anser anser domesticus) through the genotyping of the endangered zatorska breed. $B M C$ Research Notes 4(1): 65.

Bochno, R., Rymkiewicz, J. \& Szeremeta, J. 2000. Regression equations for in vivo estimation of the meat content of Pekin duck carcases. British Poultry Science 41(3): 313317.

Botstein, D., White, R.L., Skolnick, M. \& Davis, R.W. 1980. Construction of a genetic linkage map in man using restriction fragment length polymorphisms. American Journal of Human Genetics 32(3): 314-331.

Čerenak, A., Jakše, J. \& Javornik, B. 2004. Identification and differentiation of hop varieties using simple sequence 
repeat markers. Journal of the American Society of Brewing Chemists 62(1): 1-7.

Ellegren, H. 2004. Microsatellites: Simple sequences with complex evolution. Nature Reviews Genetics 5(6): 435-445.

Gaur, U., Tantia, M.S., Mishra, B., Kumar, S.T.B., Vijh, R.K. \& Chaudhury, A. 2016. Population structuring of land and coastal ducks (Anas platyrhynchos) using microsatellite markers. Current Science 110(10): 1977-1983.

Green, A.J. 1996. Analyses of globally threatened Anatidae in relation to threats, distribution, migration patterns, and habitat use. Conservation Biology 10(5): 1435-1445.

Groepper, S.R., DeLiberto, T.J., Vrtiska, M.P., Pedersen, K., Swafford, S.R. \& Hygnstrom, S.E. 2014. Avian influenza virus prevalence in migratory waterfowl in the United States, 2007-2009. Avian Diseases 58(4): 531-540.

Huang, H.L., Huang, I.Y., Lin, C.Y. \& Huang, M.C. 2013. Effective strategies for identifying novel genetic markers based on DNA polymorphisms. Journal of Molecular Biomarkers \& Diagnosis 5(1): 1000156.

Huang, Y., Tu, J., Cheng, X., Tang, B., Hu, X., Liu, Z., Feng, J., Lou, Y., Lin, L., Xu, K., Zhao, Y. \& Li, N. 2005. Characterization of 35 novel microsatellite DNA markers from the duck (Anas platyrhynchos) genome and crossamplification in other birds. Genetics Selection Evolution 37(4): 455-472.

Jin, S.D., Hoque, M.R., Seo, D.W., Paek, W.K., Kang, T.H., Kim, H.K. \& Lee, J.H. 2014. Phylogenetic analysis between domestic and wild duck species in Korea using mtDNA D-loop sequences. Molecular Biology Reports 41(3): 16451652

Jin, S.D., Hoque, M.R., Seo, D.W., Kim, I.K., Jo, C., Paek, W.K. \& Lee, J.H. 2012. Phylogenetic relationships among dabbling duck species in Korea using COI gene variations in mtDNA. The Journal of Poultry Science 49(3): 163-170.

Johnsgard, P.A. 1961. The taxonomy of the Anatidae - A behavioural analysis. The IBIS. 103A(1): 71-85.

Kraus, R.H.S., Kerstens, H.H.D., Hooft, P.V., Crooijmans, R.P.M.A., Van Der Poel, J.J., Elmberg, J., Vignal, A., Huang, Y., Li, N., Prins, H.H.T. \& Groenen, M.A.M. 2011. Genome wide SNP discovery, analysis and evaluation in mallard (Anas platyrhynchos). BMC Genomics 12(1): 150.

Matitaputty, P.R., Wijaya, C.H., Bansi, H., Laudadio, V. \& Tufarelli, V. 2015. Influence of duck species and crossbreeding on sensory and quality characteristics of Alabio and Cihateup duck meat. CyTA-Journal of Food 13(4): $522-526$.

Nei, M. 1987. Molecular Evolutionary Genetics. New York: Columbia University Press. p. 512.

Olango, T.M., Tesfaye, B., Pagnotta, M.A., Pè, M.E. \& Catellani, M. 2015. Development of SSR markers and genetic diversity analysis in enset (Ensete ventricosum (Welw.) Cheesman), an orphan food security crop from Southern Ethiopia. BMC Genetics 16(1): 98.

Rajkumar, U., Gupta, B.R. \& Reddy, A.R. 2008. Genomic heterogeneity of chicken populations in India. Journal of Animal Science 21(12): 1710-1720.

Ramey, A.M., Poulson, R.L., González-Reiche, A.S., Perez, D.R., Stallknecht, D.E. \& Brown, J.D. 2014. Genomic characterization of $\mathrm{H} 14$ subtype influenza A viruses in new world waterfowl and experimental infectivity in mallards (Anas platyrhynchos). PLoS ONE 9(5): e95620.
Rohlf, F.J. 1998. NTSYS-pc. Numerical Taxonomy and Multivariate Analysis. version 2.02. Setauket, New York: Applied Biostatistics Inc. p. 37.

Saavedra, J., Silva, T.A., Mora-Poblete, F. \& Scapim, C.A. 2013. Bayesian analysis of the genetic structure of a Brazilian popcorn germplasm using data from simple sequence repeats (SSR). Chilean Journal of Agricultural Research 73(2): 99-107.

Schlötterer, C. 2000. Evolutionary dynamics of microsatellite DNA. Chromosoma 109(6): 365-371.

Seo, D., Bhuiyan, M.S.A., Sultana, H., Heo, J.M. \& Lee, J.H 2016. Genetic diversity analysis of South and East Asian duck populations using highly polymorphic microsatellite markers. Asian-Australasian Journal of Animal Sciences 29(4): 471-478.

Simianer, H. 2006. Use of molecular markers and other information for sampling germplasm to create an animal gene bank. The role of biotechnology for the characterization and conservation of crop, forestry, animal and fishery genetic resources. International Workshop, Turin, Italy, 5-7 March 2005. pp. 37-42.

Sneath, P.H.A. \& Sokal, R.R. 1973. Numerical Taxonomy: The Principles and Practice of Numerical Classification. San Francisco: Freeman. p. 573.

Stolle, E., Kidner, J.H. \& Moritz, R.F.A. 2013. Patterns of evolutionary conservation of microsatellites (SSRs) suggest a faster rate of genome evolution in Hymenoptera than in Diptera. Genome Biology and Evolution 5(1): 151162

Susanti, R., Soejoedono, R.D., Mahardika, I.G.N. \& Wibawan, I.W.T. 2008. Prevalence of avian influenza virus subtype H5N1 in waterfowl in West Java Province of Indonesia. International Journal of Infectious Diseases 12(1): e127.

Susanti, R., Iswari, R.S., Fibriana, F. \& Sari, R.I. 2017. Mitochondrial D-loop sequence variation among Central Javanese Duck in Indonesia. Acta Scientiarum - Animal Sciences 39(4): 449-456.

Veeramani, P., Prabakaran, R., Sivaselvam, S.N., Sivakumar, T. \& Karthickeyan, S.M.K. 2014. Analysis of genetic distance for indigenous and exotic duck breeds. Journal of Poultry Science and Technology 2(4): 84-86.

Vijh, R.K., Tantia, M.S., Mishra, B. \& Kumar, S.T.B. 2008. Genetic relationship and diversity analysis of Indian water buffalo (Bubalus bubalis). Journal of Animal Science 86(7): 1495-1502.

Vijh, R., Tantia, M.S., Mishra, B. \& Settypalli, B.K. 2007. Genetic diversity and differentiation of dromedarian camel of India. Animal Biotechnology 18(2): 81-90.

Wu, F., Huang, Y., Ma, Y., Hu, S., Hao, J. \& Li, N. 2009. Evaluation of genetic diversity and relationships within and between two breeds of duck based on microsatellite markers. Progress in Natural Science 19(11): 11581-1586.

Department of Biology

Faculty of Mathematics and Natural Science

Universitas Negeri Semarang

50229 Indonesia

*Corresponding author; email: r.susanti@mail.unnes.ac.id

Received: 9 April 2019

Accepted: 24 June 2020 